\title{
Problems Associated With Conservation of Medicinal Plants in Anambra State
}

\author{
* Orji E.C., ${ }^{* *}$ Onwughalu G.I And *Nweke I.A \\ ** Dept. of Botany, Nnamdi Azikiwe University, Awka \\ * Faculty of Agriculture, Anambra State University, Igbarim Campus
}

\begin{abstract}
A questionnaire survey of the problems associated with conservation of medicinal plants in Anambra State of Nigeria was conducted using structured questionnaire forms. Three local government areas were chosen from each of the Agricultural zones of the state for the study, which was also based on prevailing sub vegetation zones. Results indicate that huge financial involvement is required to implant laudable conservation strategies: over - exploitation of the species for medicinal purposes poor environmental education of the public, uncontrolled habitat destruction and non-prioritization of species list for conservation were the major problems associated with medicinal plant conservation in the area.
\end{abstract}

Keywords: Problems conservation, medicinal plants, Anambra State.

\section{Introduction}

Over the years, plant conservationists have made conscious efforts to protect and conserve medicinal plants and thus prevent their extinction. This has not been a straightforward programme due to many problems that militate against it.

The alarming rate at which various plant species are removed from their natural habitats had been documented by many authors (Ford - Lloyd and Jackson, 1986, Akerele et al., 1991, Ledig 1992, Mulongoy et al., 1992, Mace, 1995, Orji and Ibeneme 2000, Orji 2001a, 2003c, and 2003d, Orji and Ugbaja 2008). Medicinal plants are plants adaptable to mitigate or cure various diseases. They can be used as medicines, foods or materials for pharmaceutical preparations. This interdependence of their uses provides strong concern and need for their conservation which a protective measure is taken to prevent the loss of their genetic diversity, save them from going into extinction and protect their ecosystem from damage in order to promote their sustained utilization.

In spite of all the efforts of conservationists in this regard, the control of their exploitation through protection, judicious use and efficient management so as to ensure continuous yield have still not been fully attained. This is because some hydra-headed problems continue to oppose conservation efforts. This study was undertaken to ex-ray the major problems militating against medicinal plant conservation efforts in Anambra State.

\section{Questionnaire Survey}

\section{Method of Study}

The questionnaire forms used in the survey embodied various issues relating to the problems associated with medicinal plant conservation in the area of study.

The survey was conducted in each of the three Agricultural zones of the state using one Local Government Area (L.G.A) in each Agricultural zone. Respondents were selected from traditional healers, elderly men and women, town union officials and students who were willing to be interviewed. Field assistants helped with the administration of the questionnaire, which was made up of 30 respondents for each community summing up to 90 respondents.

\section{Results}

Respondents strongly indicated that conservation problems of medicinal plants hinged on the following: over - exploitation of the plant species, uncontrolled habitat destruction, poor environmental education of the masses, non-prioritization of medicinal plant species list and high cost of implementation of conservation strategies. 
Response Of Respondents On Problems Associated With Conservation Of Medicinal Plants In The Area Of Study.

\begin{tabular}{lcc}
\hline $\begin{array}{l}\text { What are the major problems associated with conservation } \\
\text { of medicinal plants? }\end{array}$ & Number of Respondents Percentages & \\
\hline $\begin{array}{l}\text { Over-exploitation of medicinal plants in the field by } \\
\text { traditional healers and others. }\end{array}$ & 12 & 13.33 \\
$\begin{array}{l}\text { Extensive and uncontrolled habitat destruction for } \\
\text { developmental purpose. }\end{array}$ & 11 & 12.22 \\
$\begin{array}{l}\text { Poor environmental perception and education of the masses } \\
\text { on the need and methods of conservation. }\end{array}$ & 19 & 21.11 \\
$\begin{array}{l}\text { Non-prioritization of plant species list for conservation. } \\
\text { High cost of implementation conservation strategies. }\end{array}$ & 24 & 26.66 \\
\hline Total & 24 & 26.66 \\
\hline
\end{tabular}

Results of the study showed that 24 respondents each indicated that non - prioritization of medicinal plant species and high cost of implementation of conservation strategies are one of the major problems facing medicinal plant conservation. 19 respondents indicated that poor environmental perception and education was the major cause while 11 indicated that extensive and uncontrolled habitat destruction was the main cause. 12 indicated that over - exploitation of medicinal plants by herbalists and other users were the major causes of medicinal plant conservation problems.

\section{Discussion \\ OVER - EXPLOITATION OF MEDICINAL PLANT SPECIES}

In recent times, medicinal plants have been variously demanded and exploited for many reasons. Herbalists collect these plants to satisfy the growing dependence and preference of the people on herbal preparations used in solving their primary health care problems. Due to the over - increasing knowledge and acceptance of the traditional local medicines in this part of the country and, of course elsewhere, there has been an acknowledgeable increase in the use into which these medicinal plants are put. Again, as cases of disease infestation continue to rise and the cost of western medication appears unaffordable, this pattern of dependence of the people on these plants continues to rise.

HABITAT DESTRUCTION: The problem of over - population often leads to habitat destruction as natural vegetation is cleared to provide land for construction of roads, buildings, Agricultural expansion, rural and urban - related developments, excessive and uncontrolled exploitation of timber and firewood plantation, etc, $90 \%$ of the medicinal plant resources occurs in the forest sectors but the valuable natural resources of the forest and derived savanna ecosystems of the Anambra State region are rapidly being destroyed through this large scale forest clearance.

Natural disasters such as floods, gully erosions, etc, destroy millions of medicinal plants and their ecosystem in an instant, bringing to naught any prior conservation efforts.

FINANCIAL PROBLEMS: Financing conservation programmes have been a major problem militating against the success of conservation strategies. Heavy financial inputs are actually needed in order to execute laudable conservation practices. Much has been done in order to raise fund by governmental bodies and Non Governmental Organization (NGOs) but these funds are not usually sufficient for the completion of these strategies.

\section{LACK OF PROPER EDUCATION OF THE MASSES}

The conservation of medicinal plants in Anambra State cannot be effective without the active participation of local people and other stakeholders. The seeming ignorance or negligence of the people to the economics of these plants resulting in the lack of concern of the people to the disappearance of threatened species has exacerbated the problem, thereby creating enormous conservation challenges. In Anambra State, the destruction rate of the environment has so far exceeded the breeding and recovery rate that the situation can only be corrected by drastic measures and determined actions which will be effected through environmental education and training of the masses so that they will develop true consciousness of their role in their natural and human context. 


\section{PRIORITIZATION OF SPECIES TO BE CONSERVED}

The issues of the species to be conserved have posed a lot of problems to the efforts geared toward conservation of medicinal plants. Actually, a lot of research efforts had been made into the proper documentation of medicinal plants in the region. However, despite the renewed interest in this field of study, only a relatively few species have been studied exhaustively.

The problem of conservation is therefore which medicinal plants are to be conserved? Which of these species are conservationists to give priority in their conservation programme? Is it those with "established" medicinal qualities or those with "probable" medicinal attributes? What criteria establish the importance of one species over the other? This is a big problem that usually ends in confusion and conflicts among those interested in conservation such that in the long run all the conservation efforts are put on hold for want of guidelines that will assist in the process of prioritizing medicinal plant list of the area for focused conservation action.

\section{Conclusion and Recommendation}

In view of the problems associated with conservation of medicinal plants in Anambra State, it is very important to note that for any recommendation for their conservation to be effective, it must recognize and address the importance of these issues or problems discovered during the course of this study. The conservation strategy must address the problems at two levels:

a. Those that have socio - economic effects must be incorporated at the policy level and

b. Those that concern conservation methodology must be addressed at the national and local level.

These strategies should cover the following areas.

$>$ International and national policy

In-situ and ex - situ conservation method and

$>$ Education and research.

\section{References}

[1] Akerele, O., Heywood, V, and Synge, H., (1991). Conservation of medicinal plants. Cambridge University Press, Cambridge UK 480pp.

[2] Ford-LIoyd, B. and Jackson, M., (1986). Plant genetic resources, an introduction to their conservation and use. Edward Arnold publishers Ltd. London 142pp.

[3] Ledig, E.T., (1992). Human impact on genetic diversity in forest Ecosystem Oikos 63, 87 - 108

[4] Mace, G.M., (1995). Classification and its role in conservation planning In. Extinction Rates Lawton, J. and May, R.M. (Eds.). Oxford University Press. New York. $197-213$.

[5] Mulongoy, M, Gueye, Spender, D (Eds)(1992) Biology Nitrogen Fixation and sustainability of tropical Agriculture IITA Ibadan Nigeria pp21-46.

[6] Orji, E.C. and Ibeneme, C.C. (2000). Use of indigenous plants in traditional medicinal practice in Anambra State; A bio-diversity depletion for concern In: Transaction of the Nigeria society for biological conservation. A journal of the Nigerian Society for Biological Conservation (NSBC). Vol. 1 No $229-34$.

[7] Orji E.C. and Ugbaja, M.J.2008. effect of intercropping of Mricuna cercupudes with maize on the productivity of maize in the humid Tropic.J.Agric. vol.2 118-211.

[8] Orji E.C (200d) Forestry women in management and conservation. African Journal of Environmental studies. Vol 1 (Nos 1 and20, 4852).

[9] Orji E.C (2001a) Prospects and constraints in conserving indigenous fruit trees for sustainable Agricultural Development in Nigeria. African Journal of Environmental studies Vol 2: 152-156.

[10] Orji E.C (2003c) Proper utilization of indigenous fruit trees as a means of Achieving sustainable Agricultural Development in the Tropics. International Journal of Economic Development issues. Vol 3No1, June 2003. 